\title{
Impact of Working Capital Management on Profitability: A Study on Textile Companies of Bangladesh
}

\author{
Ahmed SU, Mahtab N, Islam N* and Abdullah M \\ School of Business, Independent University, Bangladesh
}

\begin{abstract}
Management of short-term assets and liabilities play vital role in generating profit in business sector. In the light of that, textile sector from all over the world is also emphasizing on to maintain optimal working capital to generate more profit. Researchers and practitioners around the world have done lot of work on how to maintain working capital in optimal level. Similarly, in Bangladesh, textile sector has concentrated to ensure efficient working capital management. But inadequate research work has been done on working capital management in textile companies of Bangladesh. On this background, the objective of this study is to examine the impact of different components of working capital management on profitability of the Bangladeshi textile companies. To examine that authors have used 8 (eight) years data from the time period of 2007-2014 of 22 textile companies listed in Dhaka Stock Exchange (DSE) and logistic regression has used to analyze the data. The findings of the study showed that, there is statistically significant relationship between working capital management and profitability of the Bangladeshi textile companies. More specifically, this study revealed that Current ratio and Current liabilities to total asset has most significant impact on profitability of textile companies in Bangladesh.
\end{abstract}

Keywords: Working capital management; Profitability; Textile sector; Bangladesh

\section{Introduction}

In the current perspective of the competitive market short-term assets and liabilities are important components of total assets and need to be analyzed carefully at the side of long-term assets and liabilities. Management of this short-term assets and liabilities are subject to investigate warily from the time because working capital management plays a vital function for the firm's profitability and risk as well as its value [1]. According to Alavinasab and Davoudi [2], "Working capital includes all short term assets which company uses it in daily activities. Working capital is an indicator for measuring the liquidity which is defined as adequacy of cash for doing firm's obligations". Generally, all short term assets which company use in daily basis is included in working capital. In the field of financial management, working capital management is a very sensitive area [3]. Working capital management is also very important for the firm's success; hence companies are trying to maintain optimal levels of working capital. Companies are adopting methods for managing proper level in various components of working capital i.e., cash receivables, inventory and payables etc. [4]. According to Pike and Neale [5], companies with improper condition of liquidity cannot pay their bills on the maturity date, in contrast companies with proper situation of liquidity have adequate cash for the payment of their bills on the maturity date. To increase the shareholder's wealth and firm's profitability, planning and policies regarding working capital management should get higher priority so that it should be done on the basis of supply chain management [2].

Similar to the other business sectors, efficient management of working capital is equally important for textile sector as well. Textile companies are dealing with accounts payables and accounts receivables routinely along with their day to day activities for purchasing raw materials and for selling products. But due to the lack of knowledge regarding the working capital and lack of management's ability to plan and control its components, textile companies are facing insolvency, in long run their performance is deteriorating and causing bankruptcy [2]. Both the practitioners and researchers have emphasized on efficient management of working capital to ensure better performance and generate more profit. Extensive research studies have been conducted previously by different researchers from different business sectors [2,6-11], from 1995 to 2013 on the relationship between working capital management and profitability in different stock exchanges in India, Pakistan, Turkey, Belgium, America and Tehran. Their research findings have concluded almost with the same findings and indicate that there is significant relationship between different variables of working capital management and firms' profitability. In respect to the importance of working capital management and inadequacy of research work on Bangladeshi textile industry, it is needed to examine working capital management of textile companies listed in the Dhaka stock exchange based on previous studies, which was done in other countries and also models or variables which were used in previous studies. In light of that this study formulation of the research is to find out the impact of different components of working capital management (cash conversion cycle, current ratio, current asset to total liabilities and current liabilities to total asset ratio) on profitability of the Bangladeshi textile companies. The questions that come to the fore are: Is there significant relationship between working capital and profitability? Are different components of working capital impact on profitability of textile companies of Bangladesh?

The uniqueness of this research is to identify the dynamics of strategic objectives, strategic policies of the textile sector of Bangladesh in order to manage working capital to achieve profitability.

*Corresponding author: Nazmul Islam, School of Business, Independent University, Plot 16, Block B, Bashundhara R/A, Dhaka-1212, Bangladesh, Tel: +8802-8431645-53; E-mail: nazmul@iub.edu.bd

Received September 11, 2017; Accepted September 25, 2017; Published October 05, 2017

Citation: Ahmed SU, Mahtab N, Islam N, Abdullah M (2017) Impact of Working Capital Management on Profitability: A Study on Textile Companies of Bangladesh. J Bus Fin Aff 6: 292. doi: 10.4172/2167-0234.1000292

Copyright: (c) 2017 Ahmed SU, et al. This is an open-access article distributed under the terms of the Creative Commons Attribution License, which permits unrestricted use, distribution, and reproduction in any medium, provided the original author and source are credited. 


\section{Brief Review of the Textile Sector of Bangladesh}

Textile sector is one of the largest and leading sectors in Bangladesh. Textile sector is the single biggest export earners for Bangladesh and it's earning 81 percent of total export earnings of the country. This sector has earned the value of over $\$ 24.49$ bn of exports in the 2013-14. Textile sector also created more than 12 lac employment opportunity; most significantly this sector has created opportunity for women. Almost 85 percent of labor force of textile industry of Bangladesh is women. Growth rate of textile industry of Bangladesh has been remarkable. In 1960 the foundation of textile sector of Bangladesh was established and in 1965-66 for the first time textile industry of this country has started to export. After liberation was in 1977-78 total nine exports oriented companies were available. But in current time there are more than 5000 textile companies are available in Bangladesh, which has great impact over the growth rate of GDP of this country. During the global economic recession when major sourcing countries dropped significantly, Bangladeshi textile industry holds its position and remained preferred by international. With the availability of cheap labor force, skilled human resource, proper planning, updated strategies; textile sector of Bangladesh is competing with many other countries and for the last three decades Bangladesh is second largest exporter of textile products in the world.

\section{Review of the Literature}

\section{Cash conversion cycle and ROA}

Cash Conversion Cycle (CCC) has immense impact on Return on Asset (ROA), which cause positive or negative impact on firm's profitability. Extensive research work has been done using these two variables in similar types of study. When the cash conversion cycle increases it leads to decrease the profitability of the firm [12]. Relationship between profitability and working capital management for listed companies of Tehran Stock Exchange for the period of 2001-2008. Where ROA is considered as a measure for capacity of profitability and the result indicate that there is a negative significant relationship between cash conversion cycle and return on asset. Also in similar sort of study it was investigated American companies for the period between 1975 and 1994 and found strong evidence of negative relationship between profitability and cash conversion cycle [7]. To investigate the relationship between working capital management and corporate profitability of listed company in the Athens Stock Exchange a study depicted significant relationship between cash conversion cycle and profitability [13]. Conversely, Hayajneh and Yassin find ROA positively affects the cash conversion cycle which is a measurement of working capital management [14]. They have analyzed the five year date of Istanbul companies.

\section{Current ratio and ROA}

Christoper et al. found negative association with ROI which is a measurement of working capital management and Current Ratio [15]. They investigated a sample of 14 corporate hospitals in India using panel data analysis from the time period between 1996/97 to 2005/06 and dependent variable was profitability and it was measured in terms of return on investment. In similar study Ganesan investigates the sample of 349 telecommunication equipment companies for the time period of 2001-2007 and also found that current ratio is negatively associated with profitability [16]. Ejelly have found negative relationship among the current ratio and profitability after analyzing listed companies in Saudi Arabia [17]. On the contrary, Alavinasab and Davoudi investigated 147 stock listed companies in Tehran stock exchange for the time period of
2005-2009 which had revealed significant relationship between current ratio and return on assets (ROA) [2].

\section{Current assets to total assets ratio and ROA}

Salman et al. have found negative significant relationship between current assets to total assets ratio with ROA through regression analysis [18]. In this study authors have used data of twenty (20) manufacturing companies listed on the Nigerian Stock Exchange for the period of 2005-2013. In a similar sort of study Sandhar and Janglani have also revealed negative and insignificant relationship between current assets to total assets ratio with ROA [19]. On the other hand, in another study a positive correlation have found between current assets to total assets ratio with ROA [20]. In this study author has analyzed data from 117 textiles firms listed on Karachi stock exchange for the period of 20052010.So in this study authors want to analyze Current Assets to Total Assets Ratio (CATAR) and Return on Assets (ROA) as an important variable to measure firm's efficiency of working capital management as well as firm's profitability.

\section{Current liabilities to total assets ratio and ROA}

Research studies have been conducted previously by different researchers by using current liabilities to total assets ratio (CLTAR) and return on assets (ROA) and researchers have found mixed opinion in different studies. Alavinasab and Davoudi [2] examined the effects of working capital management for the listed company of Tehran stock exchange for the period of 2005-2009 and negative significant relationship have been found between current liabilities to total assets ratio (CLTAR) and return on assets (ROA). In a similar sort of study Sumaira (2013) has studied the 117 companies of Pakistani textile industry and also found negative relationship between CLTAR and ROA [21]. Negative and insignificant relationship has been found between Current Liabilities to Total Assets Ratio (CLTAR) and ROA in the study on Indian Cement Company [19]. In similar sort of study Salman et al. (2014) also found negative and insignificant relationship between current liabilities to total asset ratio and ROA, in their study they have analyses 20 manufacturing companies in Nigerian stock exchange. Afza and Nazir [4] used the sample of 263 non-financial companies among 17 different sectors listed in Karachi Stock Exchange from the period of 1998 to 2003, have also found negative relationship between CLTAR and ROA.

\section{Cash conversion cycle and ROE}

Anser and Malik [22] in the study of listed manufacturing company of Pakistan on cash conversion cycle and firm's profitability have found that cash conversion cycle is significantly and inversely related to ROE. Which clearly indicate that lesser the cash conversion cycle greater the profitability if measured by the ROE. Similarly, Panigr and Rahman [10] examined 26 Pakistani companies to calculate profitability for the time period of 2004 to 2009 and have found there is no significant relationship on Current Ratio and Return on Equity. On the other hand, in similar sort of study researchers investigate the relationship between liquidity and profitability of companies listed in Saudi Stock Exchange. They have used the data of 99 listed companies in Tadawul for the time period of 2008 to 2012 and have revealed a positive relationship between Current Ratio and ROE [23].

\section{Current assets to total assets ratio and ROE}

Niresh [24] analyze the data of 30 listed manufacturing firms of Colombo Stock Exchange for the period of 2008 to 2011 and found that ROE is positively correlated with Current Assets to Total Assets Ratio 
and Return on Equity. Similarly, Mwangi et al. [25] has found positive relationship between total current assets to total assets ratio and return on equity after analyzing 42 non-financial companies listed in the Nairobi Securities Exchange, Kenya for the period of 2006-2012. On the other hand Nazir and Afza [26] have found negative relationship between Current Assets to Total Assets Ratio and Return on Equity. In their study authors have analyzed the data of 208 public limited companies listed at KSE for the time period of 1998-2005.

\section{Current liabilities to total assets ratio and ROE}

Both positive and negative relationships have been found between Current Liabilities to Total Assets and ROE in previous research work. Kamau and Ayuo in their study [27], they have found positive relationship between Current Liabilities to Total Assets and ROE. They have used 13 manufacturing company of Kenya as a sample in this study for the time period of ten years. However inverse relationship have found by Alavinasab and Davoudi [2] after analyzing the data of 147 listed companies on Tehran stock exchange for the period of 2005-2009 to study the relationship between working capital management and profitability of listed companies. Similar relationship has been found by Niresh [24] between Current Liabilities to Total Assets and ROE in the study conducted to examine the relationship between Working Capital Management \& Financial Performance of Manufacturing Sector in Sri Lanka. In this study author has used 30 listed manufacturing firms of Colombo as a sample for the time period of four years (2008-2011).

\section{Theoretical Construct}

\section{Working capital management}

Working Capital Management refers to the management decisions and strategies that are adopted by companies in order to deal with problems relating to the management of working capital, which generally influence the size and effectiveness of the working capital of a firm. In order to meet short-term debt obligations and operating expenses of a company, working capital management ensures companies have sufficient cash flow. To improve the earnings of a company, implementation of effective working capital management system is essential. Lack of efficient working capital management not only reduces profitability of a company but also has major impact on its financial leverage position, which may lead to business failure as well. However, both excessive and inadequate working capital is harmful for a firm [28]. Since excessive working capital leads to unremunerative use of scarce funds and inadequate working capital management interrupts the normal operation of a firm. The firms that manage working capital properly, have found to be able to make counter cyclical moves to build competitive advantage and they have also performed better in generating fund internally and also face lesser trouble in external financing [29].

\section{Cash conversion cycle}

Cash Conversion cycle (CCC) is the length of time between a firm's purchase of inventory and the receipt of cash from accounts receivable. CCC represents the number of day's a firm's cash remains tied up with the operations of the business. CCC is calculated by (number of days' inventories + number of days' accounts receivable) - number of days' accounts payable [30]. Richards and Loughlin [31] suggest that all relevant cash flows come from the operations considers the cash conversion cycle (receivables, inventory, and payables). The lower the cash conversion cycle, the healthier a company is. CCC can also be negative, when company has a strong position in market and can postpone its payments while purchasing from suppliers. It is important for every business to calculate cash conversion cycle. It's provide clear picture to the owner of the business about the number of days' cash or capital stays tied up in the business processes of the firm. Cash conversion cycle is a key measure of working capital efficiency. Nobanee [32] stated that effectiveness of WCM is depends on CCC, and CCC is considers all cash flows associated with inventory, accounts receivable and accounts payable.

\section{Current ratio}

The current ratio is a liquidity and efficiency ratio that measures a firm's ability to pay off its short-term liabilities with its current assets. The current ratio is an important measure of liquidity because shortterm liabilities are due within the next year.

Current Ratio (CR) is calculated by $=($ Current Assets $) /($ Current Liabilities)

Current assets like cash, cash equivalents, accounts receivable, inventory, marketable securities, and prepaid expenses can easily be converted into cash in the short term. This means that companies with larger amount of current assets will more easily be able to pay off current liabilities. In order to understand the liquidity of a company, current ratio helps investors and creditors and also its express a firm's current debt in terms of current assets. Higher current ratio is always favorable than lower current ratio.

\section{Current assets to total assets}

This represents the amount in form of current assets as per each amount invested in total assets. This key ratio represents the relationship between current assets and the balance sheet total. For day to day operations and pay on-going expenses, current asset is important [33,34].

\section{Current liabilities to total assets}

Current Liabilities to Total Assets represent the total number of current liabilities relative to total assets. Current Liabilities include short-term debt, accounts payable, accrued liabilities and other debts and total assets are total value of firm's which is always equal to the combined value of its "equity" and "liabilities". Current Liabilities to Total Assets measures the firm's ability to repay its short-term debt by indicating the percentage of a company's total assets. Higher the ratio of Current Liabilities to Total Assets, the greater risk will be associated with the firm's operation.

Also, profitability includes return on assets rate and return on equity rate.

ROA is calculated by $=$ (Operating Profit) $/$ (Total Assets)

ROE is calculated by $=($ Net Profit $) /($ Total Equities $)$

$\mathrm{ROA}=\beta_{0}+\beta_{1} \mathrm{X}_{1}+\beta_{2} \mathrm{X}_{2}+\beta_{3} \mathrm{X}_{3}+\beta_{4} \mathrm{X}_{4}+\mu$

$\mathrm{ROE}=\beta_{0}+\beta_{1} \mathrm{X}_{1}+\beta_{2} \mathrm{X}_{2}+\beta_{3} \mathrm{X}_{3}+\beta_{4} \mathrm{X}_{4}+\mu$

Where,

ROA=Return on Asset

ROE=Return on Equity

$\beta_{0}=$ Constant

$\mathrm{X}_{1}=$ Current Ratio 
$\mathrm{X}_{2}=$ Cash Conversion Cycle

$\mathrm{X}_{3}=$ Current Asset to Total Asset

$\mathrm{X}_{4}=$ Current Liabilities to Total Asset.

\section{Hypothesis}

This study covers of two main hypotheses and each of them includes four subordinate hypotheses:

a) There is a significant relation between working capital management and return on assets.

- Ha1: There is a significant relation between cash conversion cycle and return on assets.

- Ha2: There is a significant relation between current ratio and return on assets.

- Ha3: There is a significant relation between current assets to total assets ratio and return on assets.

- Ha4: There is a significant relation between current liabilities to total assets ratio and return on assets.

b) There is a significant relation between working capital management and return on equity.

- $\quad \mathbf{H}_{b} \mathbf{1}$ : There is a significant relationship between cash conversion cycle and return on equity.

- $\quad \mathbf{H}_{\mathrm{b}}$ 2: There is a significant relation between current ratio and return on equity.

- $\mathbf{H}_{\mathbf{b}}$ 3: There is a significant relation between current assets to total assets ratio and return on equity.

- $\quad \mathbf{H}_{\mathrm{b}}$ 4: there is a significant relation between current liabilities to total assets ratio and return on equity.

\section{Research Design and Sampling}

\section{Research design}

In this research, secondary data collected from the annual reports of companies has been used to test the hypothesis. The research conducted is an ex post facto study. It is a formal study where relationship with profitability is explained with the components of working capital management through the extensive use of logistic regression.

\section{Sampling}

This study was designed for testing hypotheses quantitatively which required a good number of samples which reflected the investors and foreign and native buyers. As a result, focus on longitudinal study and 8 years data of 22 randomly chosen different textile companies listed on Dhaka Stock Exchange of Bangladesh have selected as a sample. The topical scopes for this research is statistical study and have used statistical analysis to collect quantitative information because it is designed for extent instead of penetration.

\section{Data Analysis}

\section{Descriptive statistics and correlation}

Table 1 shows the Descriptive statistics and correlation for model 1. In model 1 Dependent variable is Return on asset and independent variables are Current ratio, Cash Conversion Cycle, Current asset to Total Asset Ratio and Current Liability to Total Asset Ratio. From descriptive statistics of sampled textiles, it can be said that on an average the ROA of textiles industry is $1.69 \%$ with maximum industry values as high as $52 \%$ and as low as $-61 \%$. The standard deviation of this research sample is only $12 \%$ indicating that there is not much deviation from the maximum and minimum values. Average current ratio is $151.03 \%$, indicating high level of liquid cash availability in this sector with maximum values as high as $1174 \%$. Average value of Cash Conversion Cycle also depicts a high value of 149.56 indicating that this sector is very efficient in converting their cash on hand into inventory and accounts payable, through sales and accounts receivable, and then back into cash again. However, a high standard deviation of 97.30 for CCC also means that there can be severe deviations of performance in this sector. The table also depicts that this sector has a $50 \%$ spread on an average for both Current Asset to Total Asset Ratio and Current Liability to Total Asset Ratio. From the correlation table, we can see that even though both CR and ROA and CCC and ROA has relatively low positive correlation, however it is highly significant in both the cases and this clearly depicts that in the textile industry both CR and CCC has a significant impact on the company's ROA. On the other hand, Current Assets to Total Assets ratio in the textile industry also has positive correlation with ROA, however it very weak and only has some significant effect on ROA. In contrast, from the correlation table we can see that Currents Liability to Total Assets ratio has a highly significant, even though weak, negative relation with ROA (Table 1).

Table 2 shows the Descriptive statistics and correlation for model 2. In model 2 Dependent variable is Return on Equity and independent variables are Current ratio, Cash Conversion Cycle, Current asset to Total Asset Ratio and Current Liability to Total Asset Ratio. From descriptive statistics of sampled textiles, it can be said that on an average the ROE of textiles industry is $-1.00 \%$ with maximum industry values as high as $68 \%$ and as low as $-388 \%$. The standard deviation of the sample is $44 \%$ indicating that there is a big deviation from the maximum and minimum values in some of the companies in the textile industry. Average current ratio is $167 \%$, again indicating high level of liquid cash availability in this sector, as in Model 1 with maximum values as high as

$1174 \%$. This indicates that both ROA and ROE are greatly affected by CR. Average value of Cash Conversion Cycle also depicts a high value of 149.56 indicating that this sector is very efficient in converting

\begin{tabular}{|c|c|c|c|c|c|c|c|c|c|c|c|}
\hline & $\mathbf{N}$ & Min & Max & Mean & Std. Dev & VIF & ROA & CR & CCC & CA_TA & CL_TA \\
\hline ROA & 176 & -0.61 & 0.52 & 0.017 & 0.12 & - & 1 & - & - & - & - \\
\hline $\mathrm{CR}$ & 176 & 0.11 & 11.74 & 1.51 & 1.67 & 1.503 & $0.24^{* *}$ & 1 & - & - & - \\
\hline $\mathrm{CCC}$ & 176 & -76.91 & 321.76 & 149.56 & 97.3 & 1.078 & $0.27^{\star *}$ & $0.18^{*}$ & 1 & - & - \\
\hline CA_TA & 176 & -0.43 & 1.37 & 0.5 & 0.23 & 1.476 & $0.17^{*}$ & $0.16^{*}$ & -0.02 & 1 & - \\
\hline CL_TA & 176 & -1 & 2.19 & 0.5 & 0.341 & 1.848 & $-.03^{* *}$ & $0.44^{* *}$ & $-0.25^{* *}$ & $0.42^{\star *}$ & 1 \\
\hline
\end{tabular}

${ }^{*}$ Correlation is significant at the 0.05 level (2-tailed).

${ }^{* *}$ Correlation is significant at the 0.01 level (2-tailed). 


\begin{tabular}{|c|c|c|c|c|c|c|c|c|c|c|c|}
\hline & $\mathbf{N}$ & Min & Max & Mean & Std. Dev & VIF & ROE & CR & $\mathrm{CCC}$ & CA_TA & CL_TA \\
\hline ROE & 176 & -3.88 & 0.68 & -0.01 & 0.44 & - & 1 & - & - & - & - \\
\hline CR & 176 & 0.11 & 11.74 & 1.51 & 1.67 & 1.503 & $0.15^{*}$ & 1 & - & - & - \\
\hline $\mathrm{CCC}$ & 176 & -76.91 & 321.76 & 149.56 & 97.31 & 1.078 & 0.13 & $0.18^{*}$ & 1 & - & - \\
\hline CA_TA & 176 & -0.43 & 1.37 & .50 & 0.23 & 1.476 & 0.08 & $0.16^{*}$ & -0.02 & 1 & - \\
\hline CL_TA & 176 & -1.00 & 2.19 & .50 & 0.34 & 1.848 & -0.16 & $-0.44^{\star *}$ & $-0.25^{\star \star}$ & $0.42^{* *}$ & 1 \\
\hline
\end{tabular}

${ }^{*}$ Correlation is significant at the 0.05 level (2-tailed).

${ }^{\star *}$ Correlation is significant at the 0.01 level (2-tailed).

Table 2: Descriptive statistics and correlation of model 2.

\begin{tabular}{|c|c|c|c|c|c|}
\hline & $\begin{array}{l}\text { Model-1 (Coefficient) } \\
\text { Significance* }\end{array}$ & $\begin{array}{l}\text { Model-2 (Coefficient) } \\
\text { Significance* }\end{array}$ & $\begin{array}{l}\text { Model-3 (Coefficient) } \\
\text { Significance* }\end{array}$ & $\begin{array}{l}\text { Model-4 (Coefficient) } \\
\text { Significance* }\end{array}$ & $\begin{array}{c}\text { Model-5 (Coefficient) } \\
\text { Significance }\end{array}$ \\
\hline Constant & $\begin{array}{l}(1.743) \\
0.0173^{*}\end{array}$ & $\begin{array}{l}(1.728) \\
.050^{*}\end{array}$ & $\begin{array}{l}(0.556) \\
0.544\end{array}$ & $\begin{array}{c}(-0.581) \\
0.323\end{array}$ & $\begin{array}{c}(1.437) \\
0.119\end{array}$ \\
\hline \multicolumn{6}{|l|}{$\mathrm{DV}=\mathrm{ROA}$} \\
\hline CR & ------------- & $\begin{array}{c}(0.316) \\
0.620\end{array}$ & $\begin{array}{l}(1.617) \\
0.013^{*}\end{array}$ & $\begin{array}{c}(0.323) \\
0.000717^{*}\end{array}$ & $\begin{array}{c}(0.283) \\
0.635\end{array}$ \\
\hline $\mathrm{CCC}$ & $\begin{array}{l}(0.001) \\
0.413\end{array}$ & ----------- & $\begin{array}{l}(.002) \\
0.510^{*}\end{array}$ & $\begin{array}{l}(0.002) \\
0.457\end{array}$ & $\begin{array}{c}(0.002) \\
0.474\end{array}$ \\
\hline CA_TA & $\begin{array}{l}(3.787) \\
0.002^{*}\end{array}$ & $\begin{array}{l}(3.304) \\
0.038^{*}\end{array}$ & -------------- & $\begin{array}{c}(-0.572) \\
0.527\end{array}$ & $\begin{array}{l}(3.290) \\
0.035^{\star}\end{array}$ \\
\hline CL_TA & $\begin{array}{c}(-3.918) \\
0.000021^{*}\end{array}$ & $\begin{array}{c}(-3.580) \\
0.006^{*}\end{array}$ & $\begin{array}{c}(-1.313) \\
0.068^{*}\end{array}$ & ------------- & $\begin{array}{c}(-3.444) \\
0.007^{*}\end{array}$ \\
\hline R Squared & 0.300 & 0.299 & 0.273 & 0.245 & 0.303 \\
\hline F-Statistics & 0.602 & 0.590 & $0.009^{*}$ & $0.0001^{*}$ & 0.532 \\
\hline Log Likelihood & 125.831 & 125.99 & 129.383 & 132.861 & 125.478 \\
\hline Correct Prediction & 82.955 & 82.954 & 82.944 & 85.227 & 82.900 \\
\hline
\end{tabular}

${ }^{*}$ Correlation is significant at the 0.05 level (2-tailed).

Table 3: ROA regression.

their cash on hand into inventory and accounts payable, through sales and accounts receivable, and then back into cash again.

However, a high standard deviation of 97.31 for CCC also means that there can be severe deviations of performance in this sector. The table also depicts that this sector has a $50 \%$ spread on an average for both Current Asset to Total Asset Ratio and Current Liability to Total Asset Ratio as it did in Model 1.

From the correlation table, we can see that even though both CR and ROA relatively low positive correlation, but it is significant and this clearly depicts that in the textile industry CR has a significant impact on the company's ROE. However, CCC has a low and weak correlation with that of ROE. On the other hand, Current Assets to Total Assets ratio in the textile industry also has very weak positive correlation with ROE, indicating no some significant impact on ROE. From the VIF value we can say that there is no multicollinearity between independent variables. In contrast, from the correlation table we can see that Currents Liability to Total Assets ratio has a weak, negative relation with ROE.

\section{Regression analysis}

Logistic regression was run for both the models. For the ROA model, when CR is being used as the control variable, all other variables bring about an effect of $30 \%$ on ROA and depicted by the R square of MODEL- 1 as shown in the table below. Again when CCC is being held as the control variable $\mathrm{R}$ square is $29.9 \%$ as depicted by MODEL-2. If CA_TA is the control variable, $\mathrm{R}$ square is $27 \%$ as shown in MODEL-3 of the table below. However, we see that when CL_TA is held as the control variable the impact of other variables on ROA on greatly reduced to $24.5 \%$ as shown in MODEL 4 of the Table below. As the probability F-Statistics Model 3 and 4 is less than $5 \%$, this signifies that the models are of good fit. This indicates that Current liabilities in the textile industry is a key factor in determining the ROA as when all variables are being considered in Table $3, \mathrm{r}$ square is again $30.3 \%$ which is similar to the values in MODEL 1, MODEL 2, MODEL 3 indicating that in MODEL 4 when CL_TA is kept constant, a major impact can be seen indicating that CL_TA has a significant impact on ROA.

For the ROE model, when CR is being used as the control variable, all other variables bring about an effect of $11.8 \%$ on ROE and depicted by the R square of MODEL-1 as shown in the table below. Again when CCC is being held as the control variable R square is $15.33 \%$ as depicted by MODEL-2. If CA_TA is the control variable, $\mathrm{R}$ square is $15.44 \%$ as shown in MODEL-3 of the table below. Again when CL_TA is the control variable, $\mathrm{r}$ square is almost the same of about $15.26 \%$, indicating similar effect on ROE. As the probability F-Statistics Model 3,4 and 5 is less than $5 \%$, this signifies that the models are of good fit. We can also see that when all variables are being considered the effect on the dependent variable is again almost the same with square of about $15.48 \%$. This indicates, when ROE is being considered, CR has a significant impact on ROE (Table 4).

\section{Discussion}

Our finding suggests that Current Liability to Total Asset has major impact on Return on Asset and Current Ratio has major impact on Return on Equity of RMG sector of Bangladesh. In both of the cases of regression analysis for the ROA and ROE, if we consider all other independent variables constant and only remove Current Liability to Total Asset from the regression analysis of ROA and Current Ratio from ROE, subsequently the value of R-squared decline significantly. This study clearly indicates significance relationship between Current Liability to Total Asset and ROA which replicates the findings of Alavinasab and Davoudi [2]. In addition to that this study has also found significance relationship between Current Ratio and ROE which replicates the findings of Rehman et al. [23]. On the basis of the 


\begin{tabular}{|c|c|c|c|c|c|}
\hline & $\begin{array}{l}\text { Model-1 (Coefficient) } \\
\text { Significance* }\end{array}$ & $\begin{array}{l}\text { Model-2 (Coefficient) } \\
\text { Significance* }\end{array}$ & $\begin{array}{c}\text { Model-3 (Coefficient) } \\
\text { Significance* }\end{array}$ & $\begin{array}{l}\text { Model-4 (Coefficient) } \\
\text { Significance* }\end{array}$ & $\begin{array}{c}\text { Model-5 (Coefficient) } \\
\text { Significance }{ }^{*}\end{array}$ \\
\hline Constant & $\begin{array}{l}(2.177722) \\
0.001698^{*}\end{array}$ & $\begin{array}{l}(0.787024) \\
0.389504\end{array}$ & $\begin{array}{c}(0.951505) \\
0.275598\end{array}$ & $\begin{array}{l}(0.511841) \\
0.398973\end{array}$ & $\begin{array}{c}(0.876091) \\
0.361851\end{array}$ \\
\hline \multicolumn{6}{|l|}{$\mathrm{DV}=\mathrm{ROE}$} \\
\hline CR & ------------- & $\begin{array}{l}(1.310766) \\
0.125637\end{array}$ & $\begin{array}{l}(1.252792) \\
0.029322^{*}\end{array}$ & $\begin{array}{l}(1.729503) \\
0.003435^{*}\end{array}$ & $\begin{array}{c}(1.378984) \\
0.121114\end{array}$ \\
\hline $\mathrm{CCC}$ & $\begin{array}{c}(-0.000354) \\
0.881796\end{array}$ & ------------- & $\begin{array}{c}(-0.000924) \\
0.695176\end{array}$ & $\begin{array}{c}(-0.000945) \\
0.687902\end{array}$ & $\begin{array}{c}(-0.000946) \\
0.688605\end{array}$ \\
\hline CA_TA & $\begin{array}{l}(1.734026) \\
0.090779^{*}\end{array}$ & $\begin{array}{c}(-0.262550) \\
0.863555\end{array}$ & ------------- & $\begin{array}{c}(-0.920727) \\
0.313774\end{array}$ & $\begin{array}{c}(-0.296292) \\
0.848422\end{array}$ \\
\hline CL_TA & $\begin{array}{c}(-2.273476) \\
0.001789^{*}\end{array}$ & $\begin{array}{c}(-0.555889) \\
0.620667\end{array}$ & $\begin{array}{c}(-0.738698) \\
0.288387\end{array}$ & -------------- & $\begin{array}{c}(-0.564904) \\
0.621737\end{array}$ \\
\hline R Squared & 0.118063 & 0.153329 & 0.154449 & 0.152590 & 0.154779 \\
\hline F-Statistics & 0.150090 & 0.384030 & $0.018466^{*}$ & $0.011322^{*}$ & $0.015963^{*}$ \\
\hline Log Likelihood & 138.472210 & 134.596542 & 134.471980 & 134.678536 & 134.435339 \\
\hline Correct Prediction & 82.386364 & 84.090909 & 84.659091 & 85.227273 & 85.659091 \\
\hline
\end{tabular}

${ }^{*}$ Correlation is significant at the 0.05 level (2-tailed).

\section{Table 4: ROE regression.}

findings of the study authors wants to conclude that profitability can be enhanced if firms manage their working capital in a more effective way. Moreover, as this study has found major impact of Current Ratio and Current Liability to Total Asset on profitability, authors would like to suggest to put more emphasize on CL to TA and CR to ensure efficiently manage the working capital.

\section{Policy Recommendation}

From the above discussion, it can be recommended that the textile companies of Bangladesh should draft appropriate policies to make efficient use of their working capital. Higher value of current ratio does not always indicate better position, likewise lower value of the current ratio does not always indicate weaker position, also result may vary from industry to industry.

Textile companies of Bangladesh are dealing with huge volume of inventory and inventory turnover is usually more frequent than accounts payable becomes due. On the other hand, to produce finished products companies are used to purchasing huge volume of raw materials on credit, which increase the amount of account receivables. Findings of the research also clearly indicate that current assets and current liabilities are very important components of working capital and have greater impact on profitability of textile companies. Textile companies of Bangladesh should be more concerned about both the collection of accounts receivables and settlement of account payables in due time. Companies should increase the bargaining power with both, the buyers and sellers by collecting money as early as possible and on the other hand, by holding the payment of the purchase of the raw materials as much as possible to avail the highest possible use of working capital. Also textile companies should emphasize to increase sales to increase inventory turnover and to reduce the number of days of cash conversion cycle to gain sustainable competitive advantage by managing working capital optimal level for maximizing profitability.

\section{Conclusion}

This study will subsidize to the investor to identifying how Textile companies in Bangladesh is managing their working capital. This study will provide a general agenda to researchers, strategy makers, investors and professionals to guide future researches. From this study after analyzing the eight years data of 22 Bangladeshi garments companies listed on Dhaka stock exchange, authors have come to the conclusion that among the different component of working capital management, current liability to total asset and current ratio have significant effect on profitability of the Bangladeshi garments companies and moreover, effective management of working capital have significant impact on profitability of the Bangladeshi garments companies. Proficient management of working capital has an optimistic effect on the garments' profitability. So, this study demonstrates that, an efficient working capital management can increase profitability of all garments in the textile industry of Bangladesh. This study is limited to the sample of Dhaka Stock Exchange listed textile companies only. The findings of the study could only be useful for the textile or similar sort of companies only. Future research should investigate beyond the Dhaka Stock Exchange listed textile companies. The scope of further research may extend to the working capital management including size of the company and sales growth.

\section{References}

1. Smith K (1980) Profitability versus liquidity tradeoffs in working capital management, in readings on the management of working capital. New York: St. Paul, West Publishing Company.

2. Alavinasab SM, Davoudi E (2013) Studying the relationship between working capital management and profitability of listed companies in Tehran stock exchange. Business Management Dynamics 2: 01-08.

3. Joshi P (1995) Working Capital Management under Inflation. (1st edn.), Anmo Publishers.

4. Nazir MS, Afza T (2008) Working Capital Approaches and Firm's Returns in Pakistan. Pakistan Journal of Commerce and Social Sciences 1: 25-36.

5. Pike R, Neale B (2002) Corporate finance and investment: Decisions and strategies. Financial Times/ Prentice Hall.

6. Soenen L (1993) Cash conversion cycle \& corporate profitability. Journal of Cash Management, pp: 53-58.

7. Shin HH, Soenen L (1998) Efficiency of working capital management and corporate profitability. Financial Practice and Education, pp: 364-369.

8. Marc D (2003) Does working capital management affect profitability of Belgian firms? Journal of Business, Finance and Accounting 30: 573-587.

9. Samiloglu K, Demirgunes K (2008) The Effect of Working Capital Management on Firm Profitability: Evidence from Turkey. The International Journal of Applied Economics and Finance 2: 44-50.

10. Rahman MM (2011) Working capital management and profitability: A study on textiles industry. ASA University Review 5: 59-70.

11. Muhammad M, Jan WU, Ullah K (2012) Working Capital Management and Profitability An Analysis of Firms of Textile Industry of Pakistan. Journal of Managerial Sciences VI: 156.

12. Naser M, Raheman A (2007) Working capital management and profitability- 
Citation: Ahmed SU, Mahtab N, Islam N, Abdullah M (2017) Impact of Working Capital Management on Profitability: A Study on Textile Companies of Bangladesh. J Bus Fin Aff 6: 292. doi: 10.4172/2167-0234.1000292

case of Pakistani firms. International Review of Business Research Papers 3 : 279-300.

13. Lazaridis I, Tryfonidis D (2006) Relationship between Working Capital Management and Profitability of Listed Companies in the Athens Stock Exchange. Journal of Financial Management and Analysis 19: 120-139.

14. Hayajneh OS, Yassin FL (2011) The Impact of Working Capital Efficiency on Profitability - an Empirical Analysis on Jordanian Manufacturing Firms. International Research Journal of Finance and Economics 66: 61-67.

15. Christopher SB, Kamalavalli A, Talha M (2009) Sensitivity of profitability to working capital management in Indian corporate hospitals. Working Paper.

16. Ganesan V (2007) An analysis of working capital management efficiency in telecommunication equipment industry. Rivier Academic Journal 3: 1-10.

17. Ejelly A (2004) Liquidity-Profitability Tradeoff: An empirical investigation in an emerging market. International Journal of Commerce \& Management 14: 48-61.

18. Salman A, Folajin O, Oriowo A (2014) Working Capital Maangement and Profitability: A Study of Selected Listed Manufacturing Companies in Nigerian Stock Exchange. International Journal of Academic Research in Business and Social Sciences.

19. Janglani S (2013) A Study on Liquidity and Profitability of Selected Indian Cement Companies: A Regression Modeling Approach. International Journal of Economics, Commerce and Management 1.

20. Tufail S (2013) Impact of Working Capital Management on Profitability of Textile Sector of Pakistan. 3rd International Conference of Business Management.

21. Sumaira (2013) Impact of Working Capital Management on Profitability. International Conference on Business Management.

22. Anser R, Malik (2013) Cash Conversion Cycle and Firms' Profitability-A Study of Listed Manufacturing Companies of Pakistan. IOSR Journal of Business and Management 8: 83-87.

23. Rehman MZ, Khan MN, Khokhar I (2015) Investigating Liquidity-Profitability
Relationship: Evidence from Companies Listed in Saudi Stock Exchange (Tadawul). Journal of Applied Finance \& Banking 5: 159-173.

24. Niresh AJ (2012) Working Capital Management \& Financial Performance of Manufacturing Sector in Sri Lanka. European Journal of Business and Management 4: 23-30.

25. Mwangi LW, Makau MS, Kosimbei G (2014) Effects of Working Capital Management on Performance of Non-Financial Companies Listed In NSE, Kenya. European Journal of Business and Management 6: 195-205.

26. Nazir MS, Afza T (2007) Is It Better to be Aggressive or Conservative in Managing Working Capital? Journal of Quality and Technology Management.

27. Kamau D, Ayuo A (2014) The Effects of Working Capital Management on Organizational Performance - A Survey of Manufacturing Firms in Eldoret Municipality. Research Journal of Finance and Accounting 5: 72-80.

28. Chowdhury A, Amin M (2007) Working Capital Management Practiced in Pharmaceuticals Companies Listed in Dhaka Stock Exchange. BRAC University Journal 2: 75-86.

29. Quayyum ST (2012) Relationship between Working Capital Management and Profitability in Context of Manufacturing Industries in Bangladesh. International Journal of Business and Management 7: 58-69.

30. Peavler R (2014) Cash Conversion Cycle - Converting Resources into Cash Flows.

31. Richards D, Laughlin J (1980) A cash conversion cycle approach to liquidity analysis. Financial Management, pp: 32-38.

32. Nobanee H (2009) Working capital management and firm's profitability: An optimal cash conversion cycle.

33. Metzger K (2003) Current assets to total assets.

34. Tariq B (2011) What is current asset to total asset ratio? 